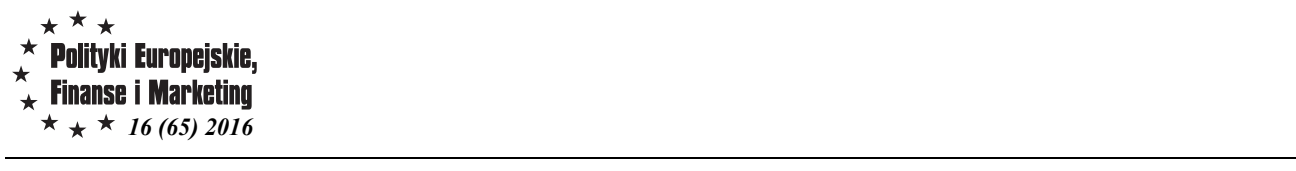

Jarostaw Świstak

Wojskowy Instytut Medyczny w Warszawie

Aleksandra Wicka

Szkoła Glówna Gospodarstwa Wiejskiego w Warszawie

\title{
Ubezpieczenia na życie w latach 2005-2014
}

\section{LIFE INSURANCE IN THE PERIOD 2005-2014}

\begin{abstract}
Celem opracowania jest określenie rozwoju ubezpieczeń na życie (grupa 1) w Polsce na tle wybranych czynników wptywajacych na liczbę $i$ wartość wyptacanych świadczeń $i$ odszkodowań. Analizy obejmowaty lata 2005-2014. Stwierdzono, że ubezpieczenia na życie (grupal) miaty $w$ badanych latach największy udziat $w$ sprzedaży ubezpieczeń osobowych. Wzrostowi liczby ubezpieczonych osób towarzyszyt 2,5 krotny wzrost wartości wyplaconych świadczeń. Ustalono także, że $w$ ubezpieczeniach na życie udziat osób objętych nimi $w$ formie grupowej byt zdecydowanie wyższy niż objętych ubezpieczeniem indywidualnym.
\end{abstract}

Słowa kluczowe: ubezpieczenia na życie, ubezpieczenia grupowe, świadczenia i odszkodowania brutto.

\section{Wprowadzenie}

Ubezpieczenia na życie stanowią ważny segment rynku ubezpieczeń gospodarczych w Polsce. Wartość składki ${ }^{1}$ pochodzącej z ich sprzedaży wynosiła w 2014 roku ponad 28,6 mld zł w wartym 54, 9 mld zł rynku ubezpieczeń. Udział ubezpieczeń na życie (dział I) w składce pochodzącej z całego rynku wynosił od 49\% w 2005 roku do $52 \%$ w 2014 roku, co świadczy o dojrzałości tego rynku². Sprzedaż ubezpieczeń na życie w 2014 roku prowadziło 27 zakładów ubezpieczeń, z czego 25 działających w formie spółek akcyjnych i 2 towarzystwa ubezpieczeń wzajemnych (Rejent Life TUW i Macif Życie TUW). Produkty ubezpieczeniowe zaliczane do działu I „Ubezpieczenia na życie”3 oferowane są w pięciu grupach ubezpieczeń - zgodnie z klasyfikacją ustawową ${ }^{4}$. W dziale I wyodrębniono następujące grupy ubezpieczeń:

1. Ubezpieczenia na życie (grupa 1).

\footnotetext{
${ }^{1}$ Wartość rynku szacowana składką przypisaną brutto, którą stanowią kwoty składek brutto należne z tytułu zawartych w okresie sprawozdawczym umów ubezpieczenia, niezależnie od tego, czy kwoty te opłacono.

${ }^{2}$ J. Handschke, J. Monkiewicz (red. nau.). Ubezpieczenia-podręcznik akademicki. Poltext. 2010

${ }^{3} \mathrm{~W}$ opracowaniu zamiennie używane będą określenia Ubezpieczenia na życie, działu I, ubezpieczenia osobowe.

${ }^{4}$ Załącznik do ustawy z dnia 11 września 2015 r. (poz. 1844). PODZIAŁ RYZYKA WEDŁUG DZIAŁÓW, GRUP I RODZAJÓW UBEZPIECZEŃ. Ustawa z dnia 11 września 2015 r. o działalności ubezpieczeniowej i reasekuracyjnej Dz. U.2015 poz.1844.
} 
2. Ubezpieczenia posagowe, zaopatrzenia dzieci (grupa 2).

3. Ubezpieczenia na życie, jeżeli są związane $\mathrm{z}$ ubezpieczeniowym funduszem kapitałowym, a także ubezpieczenia na życie, w których świadczenie zakładu ubezpieczeń jest ustalane w oparciu o określone indeksy lub inne wartości bazowe (grupa 3).

4. Ubezpieczenia rentowe (grupa 4).

5. Ubezpieczenia wypadkowe i chorobowe, jeżeli są uzupełnieniem ubezpieczeń wymienionych w grupach 1-4 (grupa 5).

Udział poszczególnych rodzajów ubezpieczeń w zakupywanych przez klientów ubezpieczeniach osobowych przedstawiono w tabeli 1.

Tabela 1. Struktura składki w ubezpieczeniach działu I w latach 2005-2014 (\%).

\begin{tabular}{|l|l|l|l|l|l|l|l|l|l|l|}
\hline \multirow{2}{*}{$\begin{array}{l}\text { Grupy działu } \\
\text { I ubezpieczeń }\end{array}$} & \multicolumn{7}{|l|}{ Struktura składki ubezpieczeniowej w dziale I (\%) } \\
\cline { 2 - 14 } & 2005 & 2006 & 2007 & 2008 & 2009 & 2010 & 2011 & 2012 & 2013 & 2014 \\
\hline Grupa 1 & 45,0 & 38,4 & 38,6 & 72,8 & 63,5 & 59,7 & 52,8 & 53,3 & 53,3 & 37,1 \\
\hline Grupa 2 & 1,0 & 0,7 & 0,5 & 0,3 & 0,4 & 0,4 & 0,4 & 0,3 & 0,3 & 0,4 \\
\hline Grupa 3 & 36,6 & 46,0 & 46,9 & 16,1 & 21,3 & 25,8 & 32,4 & 33,1 & 33,1 & 44,0 \\
\hline Grupa 4 & 0,2 & 0,2 & 0,2 & 0,2 & 0,2 & 0,3 & 0,3 & 0,3 & 0,3 & 0,4 \\
\hline Grupa 5 & 16,4 & 14,4 & 13,6 & 10,5 & 14,4 & 13,6 & 14,0 & 12,9 & 12,9 & 18,1 \\
\hline Reasekuracja czynna & 0,8 & 0,3 & 0,2 & 0,1 & 0,2 & 0,2 & 0,1 & 0,1 & 0,1 & 0,1 \\
\hline
\end{tabular}

Źródło: Opracowanie własne na podstawie danych KNF

Z analizy danych w tabeli 1 wynika, że w latach 2005-2014 największym zainteresowaniem klientów zakładów ubezpieczeń cieszyły się klasyczne ubezpieczenia na życie (grupa 1). Ich średni udział w strukturze składki w tym okresie wynosił 51,5\%. $\mathrm{Na}$ drugim miejscu były ubezpieczenia na życie $\mathrm{z}$ ubezpieczeniowym funduszem kapitałowym (UFK), czyli takie, w których składka przeznaczana jest w części na ochronę ubezpieczeniowa, a w części na inwestycje. Średnio ich udział w składce pochodzącej ze sprzedaży ubezpieczeń osobowych w latach 2005-2014 wynosił 33,5\%. Większa atrakcyjność produktów $\mathrm{z}$ grupy 3 była $\mathrm{w}$ niektórych latach związana $\mathrm{z}$ możliwością uniknięcia, tzw. podatku Belki. Płacenia podatku można było uniknąć w przypadku zakupu polisolokat. Od stycznia 2016 roku nie jest to już możliwe.

Przedmiotem niniejszego opracowania są ubezpieczenia na życie (grupa 1) oferowane w formie indywidualnej i grupowej.

Cel i metoda

Celem opracowania jest określenie rozwoju ubezpieczeń na życie (grupa 1) w Polsce w latach 2005-2014 na tle wybranych czynników wpływających na liczbę i wartość wypłacanych świadczeń i odszkodowań.

W opracowaniu zwrócono uwagę na zróżnicowanie warunków wypłaty świadczenia, a w szczególności na różne definicje zawarte w ogólnych warunkach ubezpieczenia, które mają wpływ na ustalanie ich wielkości. Oszacowana została także średnia wartość odszkodowania przypadającego na jedną wypłatę.

Dane liczbowe wykorzystane w niniejszym opracowaniu pochodziły ze źródeł wtórnych. Były to opracowania: Komisji Nadzoru Finansowego (KNF), Polskiej Izby 
Ubezpieczeń (PIU) i Głównego Urzędu Statystycznego (GUS). W artykule wykorzystano także informacje pochodzące $\mathrm{z}$ literatury przedmiotu oraz czasopism naukowych i branżowych. Przy omawianiu kwestii medycznych i porównywaniu definicji wypadków ubezpieczeniowych, stosowanych przez ubezpieczycieli odwołano się także do wiedzy i doświadczenia klinicznego specjalisty neurologa pracującego w Wojskowym Instytucie Medycznym w Warszawie, będącego współautorem niniejszego opracowania. Okres badań obejmował lata 2005-2014.

W analizie danych wykorzystano podstawowe wskaźniki statystyczne, tj. wskaźnik udziału, wskaźnik dynamiki o podstawie stałej, współczynnik korelacji i metodę opisową.

\section{Rodzaje ubezpieczeń związanych ze śmiercią jako przyczyną wyplaty świadczenia}

W powszechnym rozumieniu istotą ubezpieczenia na życie jest zapewnienie środków bliskim ubezpieczonemu po jego śmierci. W większości przypadków potrzeba zaspokojenia poczucia bezpieczeństwa finansowego rodziny jest główną przesłanką decyzji o ich zakupie. ${ }^{5}$

Zakłady ubezpieczeń rzadko w swojej ofercie mają ubezpieczenia, w których jedynym rodzajem wypadku ubezpieczeniowego jest śmierć. Zazwyczaj są to ubezpieczenia mieszane, w których ochroną objęte są śmierć i dożycie przez ubezpieczonego określonego wieku.

W obrębie ubezpieczeń na wypadek śmierci wyróżnia się dwa rodzaje ubezpieczeń. Są to ubezpieczenia terminowe i ubezpieczenia na całe życie. Biorąc pod uwagę ten rodzaj klasyfikacji w ubezpieczeniach zaliczanych do grupy 1 można wyróżnić:

Ubezpieczenia terminowe na wypadek śmierci.

1. Ubezpieczenia na całe życie (do 100 lat).

2. Ubezpieczenia na dożycie.

3. Ubezpieczenia na życie i dożycie.

Wśród ubezpieczeń terminowych na wypadek śmierci, których głównym celem jest pokrycie potrzeb wywołanych zgonem ubezpieczonego występować mogą natomiast następujące ich warianty:

1. ubezpieczenia terminowe stałe.

2. ubezpieczenia terminowe odnawialne.

3. ubezpieczenia terminowe zamienne.

4. ubezpieczenia terminowe $\mathrm{z}$ możliwością wzrostu bądź automatycznym wzrostem.

5. ubezpieczenia terminowe malejące:

- $\quad$ powiązane z kredytem.

- $\quad$ stanowiące zabezpieczenie dochodu rodzinie.

6. ubezpieczenia terminowe dla przedsiębiorstw:

- ubezpieczenie kluczowych pracowników,

\footnotetext{
${ }^{5} \mathrm{~m}$ in. wyniki badań: B. Nowotarska-Romaniak. Zachowania klientów indywidualnych w procesie zakupu usługi ubezpieczeniowej. Wolters Kluwer Business, 2013 s.148, D. Maison. Polak w świecie finansów. Wydawnictwo Naukowe PWN, 2013, s-139
} 
- $\quad$ ubezpieczenie na życie wspólnika. ${ }^{6}$

Innym podziałem ubezpieczeń na życie jest ich klasyfikacja ze względu na kryterium jakie stanowi liczba podmiotów objętych ochroną ubezpieczeniową $\mathrm{w}$ ramach jednej umowy. Na jego podstawie wyróżnia się ubezpieczenia indywidualne i ubezpieczenia grupowe. W sytuacji kiedy umowę ubezpieczenia zawiera $\mathrm{z}$ ubezpieczycielem osoba, która chce ustanowić ochronę ubezpieczeniową dla określonego dobra od skutków określonego ryzyka mamy do czynienia $\mathrm{z}$ ubezpieczeniem indywidualnym. Natomiast ubezpieczenia grupowe są ubezpieczeniami na cudzy rachunek. W polskich warunkach prawnych podmiot objęty tą ochroną, nie będący ubezpieczającym, musi wyrazić na nią zgodę. Szczegółowe regulacje prawne dotyczące tego rodzaju ubezpieczeń zawarte są w nowej ustawie o działalności ubezpieczeniowej ${ }^{7}$, która zawiera dużą liczbę regulacji ich dotyczących. W opinii Ministerstwa Finansów na temat wprowadzonych zmian, można znaleźć informację, że dzięki nowym regulacjom $\mathrm{w}$ tym obszarze nastąpi : „wzmocnienie praw osób ubezpieczonych $\mathrm{w}$ ubezpieczeniach na cudzy rachunek, w szczególności w ubezpieczeniach grupowych, przez wprowadzenie zakazu pobierania przez ubezpieczającego wynagrodzenia, zapewnienie ubezpieczonemu informacji o warunkach umowy oraz obowiązku zakładu ubezpieczeń do przekazania ubezpieczonemu, a także jego spadkobiercom, informacji związanych z przebiegiem likwidacji szkody". Większość zapisów, które znalazły się w ustawie o działalności ubezpieczeniowej dotyczących ubezpieczeń grupowych jest wynikiem nieprawidłowości $\mathrm{w}$ ich funkcjonowaniu mających miejsce w poprzednich latach, szczególnie w obszarze bancassurance ${ }^{8}$.

$\mathrm{Z}$ punktu widzenia niniejszego opracowania istotny jest fakt, iż ubezpieczenia grupowe, szczególnie pracownicze, ze względu na liczbę podmiotów uczestniczących w jednej umowie zawierane sa, w porównaniu do umów zwieranych indywidualnie, na atrakcyjnych warunkach. Ubezpieczenia pracownicze były i są bardzo atrakcyjne cenowo, jak i w odniesieniu do zakresu ochrony9. Korzyści związane z przystapieniem do ochrony ubezpieczeniowej w formie grupowej dotyczą m.in. typów świadczeń, które są w ich ramach wypłacane a dotyczą np. sytuacji śmierci w ubezpieczeniach na życie.

Podstawowe informacje o zainteresowaniu ubezpieczeniami na życie w formie grupowej i indywidualnej zawarto w tabeli 2

\footnotetext{
${ }^{6}$ E. Stroiński. Ubezpieczenia na życie. Teoria i Praktyka. Wydawnictwo Poltext Warszawa 2004, s. 109

${ }^{7}$ Ustawa z dnia 11 września 2015 r. o działalności ubezpieczeniowej i reasekuracyjnej Dz. U.2015 poz. 1844.

Szczególnie art.18,19.

${ }^{8}$ Więcej na ten temat np. M. Więcko, Podstawowe problemy bancassurance w Polsce-raport Rzecznika Ubezpieczonych-co dalej? Monitor Ubezpieczeniowy 2009 nr 37, s. 17-21.

9 M. Więcko-Tułowiecka. Ubezpieczenia grupowe z perspektywy konsumenta, w: Ochrona konsumentów na rynku ubezpieczeniowym w Polsce. Współczesne wyzwania. (red.) Jan Monkiewicz, M. Orlicki. Poltext 2015, s.43
} 
Tabela 2. Podstawowe dane charakteryzujące popyt na ubezpieczenia na życie (grupa1) w latach 2005-2014

\begin{tabular}{|c|c|c|c|c|c|c|c|c|c|c|}
\hline Wyszczególnienie & \multicolumn{10}{|c|}{ Lata } \\
\hline Indywidualne & 2005 & 2006 & 2007 & 2008 & 2009 & 2010 & 2011 & 2012 & 2013 & 2014 \\
\hline $\begin{array}{l}\text { Liczba polis } \\
\text { (indywidualne w mln) }\end{array}$ & 1,3 & 1,2 & 7,4 & 7,3 & 7,2 & 7,1 & 6,6 & 6,8 & 6,6 & 6,5 \\
\hline $\begin{array}{l}\text { Składka na życie } \mathrm{w} \\
\text { mld. }\end{array}$ & 2,04 & 1,88 & 3,49 & 9,60 & 7,04 & 7,04 & 4,94 & 4,98 & 3,96 & 3,40 \\
\hline $\begin{array}{l}\text { Liczba osób objętych } \\
\text { ubezpieczeniem w } \\
\text { mln. }\end{array}$ & 1,3 & 1,3 & 7,4 & 7,4 & 7,2 & 7,1 & 6,9 & 6,8 & 6,6 & 6,5 \\
\hline \multicolumn{11}{|l|}{ Grupowe } \\
\hline $\begin{array}{l}\text { Liczba polis (grupowe } \\
\text { w mln.) }\end{array}$ & 6,6 & 6,5 & 0,27 & 0,29 & 0,31 & 0,33 & 0,36 & 0,40 & 0,38 & 0,85 \\
\hline $\begin{array}{l}\text { Składka na życie } \\
\text { (mld) }\end{array}$ & 4,8 & 6,2 & 6,3 & 18,7 & 12,1 & 11,7 & 11,9 & 14,4 & 9,2 & 7,2 \\
\hline $\begin{array}{l}\text { Liczba osób objętych } \\
\text { ubezpieczeniem (mln) }\end{array}$ & 21,6 & 25,4 & 20,5 & 20,4 & 21 & 21,5 & 20,3 & 19,9 & 19,6 & 19,8 \\
\hline $\begin{array}{l}\text { Udział w składce } \\
\text { ogółem składki z } \\
\text { ubezpieczeń } \\
\text { grupowych }(\%)\end{array}$ & 70,3 & 76,8 & 64,5 & 66,2 & 63,3 & 62,5 & 70,6 & 74,3 & 69,8 & 67,9 \\
\hline $\begin{array}{l}\text { Udział w składce } \\
\text { ogółem składki z } \\
\text { ubezpieczeń } \\
\text { indywidualnych (\%) }\end{array}$ & 29,7 & 23,2 & 35,5 & 33,8 & 36,7 & 37,5 & 29,4 & 25,7 & 30,2 & 32,1 \\
\hline Razem & 100,0 & 100,0 & 100,0 & 100,0 & 100,0 & 100,0 & 100,0 & 100,0 & 100,0 & 100,0 \\
\hline $\begin{array}{l}\text { Udział liczby osób } \\
\text { objętych } \\
\text { ubezpieczeniem } \\
\text { grupowym w liczbie } \\
\text { ubezpieczonych } \\
\text { ogółem }(\%)\end{array}$ & 94,29 & 95,26 & 73,51 & 73,38 & 74,29 & 75,20 & 74,62 & 74,56 & 74,90 & 75,27 \\
\hline
\end{tabular}

Źródło. Opracowanie własne na podstawie danych KNF.

Na podstawie analizy danych zestawionych w tabeli 2 można stwierdzić, że od 2005 roku odnotowano prawie pięciokrotny wzrost liczby zakupionych polis w ubezpieczeniach indywidualnych na życie. Ich liczba w 2005 r. wynosiła 1,3 mln, natomiast w 2014 r. było to już ponad 6,5 mln. Nastąpił też wzrost liczby osób objętych ubezpieczeniem z ponad $22 \mathrm{mln}$ osób w 2005 roku do 26 mln w 2014 roku. Udział osób objętych ubezpieczeniem w formie grupowej był zdecydowanie wyższy niż objętych ubezpieczeniem indywidualnym. W 2005 roku udział ubezpieczonych osób w ubezpieczeniach grupowych wynosił $94,3 \% \mathrm{w}$ stosunku do ogółem ubezpieczonych w grupie 1. W kolejnych latach systematycznie zmniejszał się osiągając w 2014 roku wciąż wysoki poziom $75,3 \%$. 
Tak wysoki udział osób ubezpieczonych w formie grupowej w stosunku do ogółem ubezpieczonych na życie wynikał między innymi z ceny takiego ubezpieczenia, ale także z powszechności sprzedaży tych produktów przez banki przy okazji realizacji akcji kredytowej ${ }^{10}$.

\section{Wartość i struktura świadczeń wyplacanych $z$ ubezpieczeń na życie (grupa 1)}

W typowych ubezpieczeniach na życie, gdzie zdarzeniem losowym powodującym wypłatę świadczenia jest śmierć ubezpieczonego mamy do czynienia z sytuacją, w której to osoba trzecia otrzymuje wypłatę, gdyż osoba ubezpieczona nie żyje ${ }^{11}$. W polskim prawie (art. 831 kodeksu cywilnego) zasadą jest w związku z tym, iż to ubezpieczony w czasie trwania umowy decyduje, kto dostanie świadczenie w razie jego śmierci. Przepisy nie wprowadzają tutaj żadnych ograniczeń, nie ma zatem, np. obowiązku wskazania kogoś z najbliższej rodziny. Uprawnionym do świadczenia może być dowolny podmiot, niekoniecznie osoba fizyczna, ale także osoba prawna (np. bank). Dopiero przy braku wskazania osoby uprawnionej świadczenie od zakładu ubezpieczeń otrzymają spadkobiercy ubezpieczonego ${ }^{12}$.

Wypłaty świadczeń z ubezpieczeń na życie zależą od wielu czynników o charakterze ekonomicznym i demograficznym. Wśród nich najistotniejsze to: liczba ubezpieczonych klientów, liczba zdarzeń, które powodują wypłatę świadczenia oraz sumy ubezpieczeń, gdyż od tego czynnika zależy wprost wartość świadczenia, które będzie wypłacone uposażonym. W przypadku ubezpieczeń grupy 1 wypadkiem ubezpieczeniowym skutkującym wypłatą świadczenia jest zgon ubezpieczonego.

W tabeli 3 przedstawiono podstawowe dane odzwierciedlające stan ubezpieczeń na życie w badanych latach.

Tabela 3. Podstawowe informacje dotyczące ubezpieczeń na życie (grupa 1) w latach 2005-2014

\begin{tabular}{|l|l|l|l|l|l|l|l|l|l|l|}
\hline Wyszczególnienie & 2005 & 2006 & 2007 & 2008 & 2009 & 2010 & 2011 & 2012 & 2013 & 2014 \\
\hline Liczba polis na życie & 7,94 & 7,79 & 7,67 & 7,69 & 7,52 & 7,41 & 7,28 & 7,19 & 6,97 & 7,35 \\
\hline Liczba wypłat & 1,41 & 1,40 & 1,40 & 1,51 & 1,69 & 1,34 & 1,63 & 1,65 & 1,72 & 1,54 \\
\hline $\begin{array}{l}\text { Wypłacone } \\
\text { świadczenia w tys. zł }\end{array}$ & 4,38 & 4,87 & 5,32 & 11,21 & 21,70 & 16,09 & 18,37 & 17,35 & 13,70 & 10,56 \\
\hline $\begin{array}{l}\text { Liczba osób objętych } \\
\text { ubezpieczeniem }\end{array}$ & 22,9 & 26,7 & 27,9 & 27,7 & 28 & 28,5 & 27,2 & 26,7 & 26,2 & 26,3 \\
\hline $\begin{array}{l}\text { Kwota świadczenia } \\
\text { na 1 wypłatę (zł) }\end{array}$ & 3092 & 3465 & 3789 & 7417 & 12826 & 11975 & 11229 & 10472 & 7952 & 6839 \\
\hline
\end{tabular}

Źródło: Opracowanie własne na podstawie danych GUS i KNF.

\footnotetext{
${ }^{10}$ www.knf.gov.pl

${ }^{11}$ Więcej na ten temat: M. Szczepańska - Osoba uprawniona do otrzymania sumy ubezpieczenia w umowie ubezpieczenia na życie (uposażony) - Rozprawy Ubezpieczeniowe nr 7(2/2009), M. Krajewski, Ubezpieczenie na rzecz osoby trzeciej (w:) A. Koch (red.), Umowa ubezpieczenia Aktualne problemy prawne, Bydgoszcz - Poznań 2005, s. 70.

${ }^{12}$ D. Leśniak, E. Sienicka, B. Wojno. Zakłady ubezpieczeń i ich usługi. Poradnik KNF. CEDUR. 2014, s. 31
} 
W latach 2005-2014 obserwowano systematyczny wzrost wartości wypłacanych świadczeń z ubezpieczeń na życie. Ich wartość w 2005 roku wynosiła ok. 4,4 mld zł. a w 2014 było to już ponad 10,5 mld. Był to prawie 2,5 krotny ich wzrost, co potwierdzają również wskaźniki dynamiki obliczone dla wartości wypłacanych świadczeń (rys. 1). Najwyższą ich wartość odnotowano w 2009 roku, kiedy z ubezpieczeń na życie wypłacono świadczenia na kwotę ponad 21,7 mld. zł. Najwyższą kwotę świadczenia przypadającego na jedną wypłatę odnotowano także w 2009 roku i wynosiła ona ponad 12,8 tys. zł. Współczynnik korelacji obliczony dla wartości wypłaconych świadczeń z ubezpieczeń na życie i wartości składek wynosił 0,62, co wskazuje na dodatnią, umiarkowaną zależność między tymi dwoma zmiennymi.

Należy się spodziewać, że wartość wypłacanych przez ubezpieczycieli świadczeń będzie systematycznie wrastała gdyż wiek osób przystępujących do ubezpieczeń na życie w latach 90. ubiegłego wieku, którzy stanowią liczną grupę ubezpieczonych, będzie w najbliższych latach zbliżał się do wieku, który, statystycznie rzecz biorąc, może być jedną z przyczyn zajścia wypadku ubezpieczeniowego w ubezpieczeniach na wypadek śmierci, ale także w tych na dożycie.

Spowoduje to, że klienci, których dotychczas wpłacone składki stanowiły źródło przychodów ubezpieczycieli, staną się źródłem kosztów, ze względu na wypłacane świadczenia.

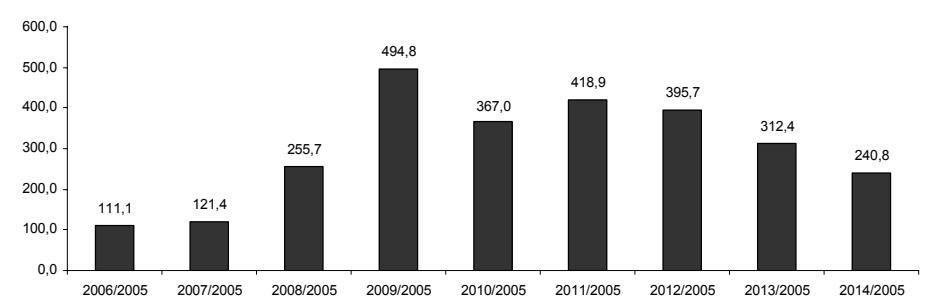

Rysunek 1. Wskaźniki dynamiki o podstawie stałej dla wartości wypłacanych świadczeń w latach 2005-2014

Źródło: Opracowanie własne na podstawie danych KNF.

\section{Wybrane czynniki wpływające ma wypłatę świadczenia ubezpieczeniowego $\mathrm{w}$ ubezpieczeniach na życie - ubezpieczenia indywidualne a ubezpieczenia grupowe}

Przedmiotem ubezpieczenia w ubezpieczeniach na życie jest życie ubezpieczonego, podstawowym ryzykiem objętym ochroną jest zaś ryzyko śmierci. Śmierć jest zdarzeniem o charakterze pewnym, nieznany jest tylko czas jej wystąpienia. Stąd też w terminologii angielskiej ubezpieczenia na życie, a dokładnie ta ich część, która dotyczy ryzyka, które musi się zrealizować, określana jest terminem assurance, a nie insurance ${ }^{13}$. Wypadkiem ubezpieczeniowym z powodu którego ma miejsce wypłata świadczenia, jest

13 A. Śliwiński. Ryzyko w ubezpieczeniach na życie taryfy - budowa i optymalizacja. http://www.gu.com.pl/index.php?option=com_content\&view=article\&id=9019\&catid=129:rynekubezpieczeniowy\&Itemid=151 [dostęp 7.11.2016 r.] 
śmierć ubezpieczonego, która jednak nie została zdefiniowana w ogólnych warunkach ubezpieczenia. Poza tym w ramach ubezpieczeń na życie mogą być objęte ochroną również inne zdarzenia np. śmierć rodzica, śmierć dziecka lub śmierć współmałżonka. Ubezpieczyciele wypłacają zatem świadczenie w sytuacji zgonu $^{14}$ ubezpieczonego opierając się na przepisach prawa cywilnego ${ }^{15}$.

Przyczyna zgonu w ubezpieczeniach na życie należących do grupy $1 \mathrm{z}$ reguły nie jest uwzględniana i nie ma wpływu na wartość wypłacanego świadczenia. Wyjątek stanowią samobójstwo i samookaleczenie, które zazwyczaj wskazywane są w ogólnych warunkach ubezpieczenia jako, tzw. wyłączenia odpowiedzialności zakładu ubezpieczeń. Tego rodzaju zdarzenia generalnie nie są przez ubezpieczycieli traktowane jako wypadek ubezpieczeniowy i nie skutkują wypłatą świadczenia. Zdarzają się jednak w ogólnych warunkach ubezpieczeń niektórych ubezpieczycieli zapisy wskazujące na fakt, iż jeśli śmierć ubezpieczonego w wyniku samobójstwa nastapi po okresie 2 lat od zawarcia umowy ubezpieczenia, to nie będzie stanowiło to podstawy do wyłączenia odpowiedzialności. ${ }^{16}$ Oznacza to, że $\mathrm{w}$ takiej sytuacji świadczenie jest wypłacane. Swoisty okres karencji, wynoszący zazwyczaj dwa lata, jest próbą wyeliminowania z ubezpieczeń osób, które chciałyby przystapić do nich z zamiarem wyłudzenia świadczenia ${ }^{17} \mathrm{w}$ wyniku realizacji tzw. hazardu moralnego.

Niektóre $\mathrm{z}$ zakładów ubezpieczeń funkcjonujących $\mathrm{w}$ Polsce oferują ubezpieczenia na wypadek zgonu ubezpieczonego z uwzględnieniem jego przyczyny, którą może być zawał serca i udar mózgu. ${ }^{18} \mathrm{~W}$ takiej sytuacji w ogólnych warunkach ubezpieczenia muszą zostać zdefiniowane te pojęcia. Także oferta ubezpieczeń na życie, która kierowana jest do klientów zakupujących je w formie grupowej, wydaje się być pod tym względem atrakcyjniejsza, w stosunku do oferty dla klientów indywidualnych. Wielu ubezpieczycieli klientom w tzw. ,grupówkach” proponuje opcję dodatkowa, podwyższającą wypłatę świadczenia ubezpieczeniowego wypłacanego z tytułu śmierci ubezpieczonego, uzależnioną od przyczyny zgonu (za stosunkowo niewielką kwotę składki). W tym przypadku przyczyna śmierci staje się istotna, gdyż znaczne podwyższenie wypłaty występuje w przypadku zgonu ubezpieczonego, którego przyczyną jest np. udar mózgu lub zawał serca. Zdarzenia te zaliczane są do chorób układu krążenia, które w Polsce od wielu lat są najczęstszą przyczyną zgonów (tab.4)

\footnotetext{
14 Zgon to nieodwracalne ustanie czynności narządów niezbędnych dla życia, konsekwencją czego jest ustanie czynności całego ustroju. (metodologia - Rocznik demograficzny GUS).

${ }^{15}$ M. Szczepańska. 2008. Ubezpieczenia na życie. Aspekty prawne. Oficyna a Wolters Kluwer business s. 245.

${ }^{16} \mathrm{~Np}$. Ogólne warunki ubezpieczenia indywidualnie kontynuowanego /www.pzu.pl/ [dostęp 7.11.2016 r.]

${ }^{17}$ Więcej na ten temat: Analiza danych dotyczących przestępstw ujawnionych w $2014 \mathrm{r}$. w związku z działalnością zakładów ubezpieczeń- członków Polskiej Izby Ubezpieczeń. https://www.piu.org.pl/[dostęp 7.11.2016 r.],

A. Luterek. Przestępczość ubezpieczeniowa w Polsce. Skala zjawiska w: Ubezpieczenia na rzecz gospodarki globalnej sektorów i regionów. I. Jędrzejczyk (red.). 2015. Oficyna wydawnicza Edward Mitek. s. 141-149.

${ }_{18}$ M. Szczepańska 2008. Ubezpieczenia na życie. Aspekty prawne. Oficyna a Wolters Kluwer business s .248 .
} 
Tabela 4. Zgony w Polsce wg. wybranych przyczyn w latach 2005-2013.

\begin{tabular}{|c|c|c|c|c|c|c|c|c|c|}
\hline \multirow[b]{2}{*}{ Zgony wg. przyczyn } & 2005 & 2006 & 2007 & 2008 & 2009 & 2010 & 2011 & 2012 & 2013 \\
\hline & \multicolumn{9}{|c|}{$(\%)$} \\
\hline Choroby układu krążenia & 45,7 & 45,5 & 45,4 & 45,6 & 46,2 & 46 & 45,2 & 46,1 & 45,8 \\
\hline Nowotwory złośliwe & 24,5 & 24,7 & 24,6 & 24,5 & 24,2 & 24,5 & 24,6 & 24,6 & 24,3 \\
\hline Urazy i zatrucia & 6,9 & 6,8 & 6,6 & 6,7 & 6,3 & 6,2 & 6,3 & 6,1 & 5,8 \\
\hline Wypadki drogowe & 1,37 & 1,5 & 1,39 & 1,38 & 1,08 & 1,1 & 1,09 & 0,81 & 0,73 \\
\hline Samobójstwa & 1,64 & 1,5 & 1,4 & 1,5 & 1,68 & 1,68 & 1,63 & 1,65 & 1,6 \\
\hline Przyczyny niedookreślone & 6,6 & 6,8 & 6,7 & 6,4 & 6,2 & 6,5 & 6,4 & 5,9 & 6,4 \\
\hline
\end{tabular}

Źródło: Opracowanie własne na podstawie Roczników Demograficznych ludności za lata 20052014.

Choroby układu krążenia, jak wynika $\mathrm{z}$ analizy danych zestawionych w tabel 4, w latach 2005-2013 każdego roku były przyczyną ponad 45 \% zgonów, natomiast nowotwory złośliwe ponad $24 \%$.

Struktura zgonów według przyczyn jest również istotnie zróżnicowana w zależności od wieku osób zmarłych. Wśród osób do 65 roku życia to nowotwory złośliwe są najczęstszą przyczyną umieralności stanowiąc 31\% wszystkich zgonów. Kolejną grupą przyczyn są choroby układu krążenia (blisko 28\%) oraz urazy i zatrucia (ponad 14\%). Sytuacja jest odmienna w przypadku zgonów osób w wieku 65 lat i więcej; ponad połowę (53\%) wszystkich przyczyn zgonów w tej grupie wieku stanowią choroby układu krążenia, kolejne $22 \%$ zgonów to nowotwory złośliwe, następnie choroby układu oddechowego - prawie $7 \%$, tj. prawie dwukrotnie więcej niż w grupie osób poniżej 65 lat $^{19}$.

$\mathrm{W}$ praktyce ubezpieczeniowej przyczyny zgonów są również bardzo istotne $\mathrm{z}$ punktu widzenia szacowania ryzyka śmierci, obok takich klasyfikacji ryzyka, w których dzieli się klientów według innych przyczyn zgonu, np. palący, niepalący, czy według rodzaju wykonywanego zawodu: administracja, robotnicy, strażacy, policjanci itd.

W tym miejscu należy zwrócić uwagę na fakt, iż ubezpieczyciele dążąc do bezwzględnego powodzenia biznesu ubezpieczeniowego, który opiera się zresztą na zaufaniu społecznym, dotyczącym, między innymi gwarancji wypłaty określonego świadczenia, powinni nieustannie poszukiwać czynników determinujących poziom ryzyka śmierci, która jest główną przesłanką decydującą o wypłacie świadczenia głównego.

Zakłady ubezpieczeń, które w swojej ofercie produktowej uwzględniają udar i zawał serca jako przyczynę śmierci i jednocześnie zdarzenie, którego wystapienie podwyższa wysokość wypłacanego świadczenia, definiują je w różny sposób. Nie zawsze umożliwia to zakwalifikowanie tych zdarzeń jako wypadków ubezpieczeniowych. Z przykładem zapisu definicji zawału serca niekorzystnej dla klientów, co ogranicza możliwość wypłaty im odszkodowania można zapoznać się, analizując np. decyzję Prezesa Urzędu Ochrony Konkurencji i Konsumentów

19 Podstawowe informacje o rozwoju demograficznym Polski do 2014 roku. Notatka informacyjna. GUS. 2015, s.11. 
(DECYZJA RWR 28/2010). W tejże decyzji uznano za praktykę naruszającą zbiorowe interesy konsumentów stosowanie $w$ ogólnych warunkach ubezpieczeń definicji, zgodnie z którą uznanie jednostki chorobowej za zawał serca uzależnione jest od: „Pojawienia się patologicznego załamka Q w EKG (nieobecnego przed zdarzeniem), podczas gdy zawał serca powstaje także wtedy, gdy załamek Q się nie pojawi”. Nakazano ubezpieczycielowi zaniechania stosowania takiego zapisu, jednocześnie nakładając karę pieniężną, płatną do budżetu państwa w wysokości 3967296 zł.

Według aktualnego stanu wiedzy medycznej, występowanie załamka Q w klinicznym obrazie zawału serca nie jest konieczne dla stwierdzenia zawału. Moga pojawić się inne okoliczności świadczące o zawale serca. Stosowanie zatem przez ubezpieczycieli we wzorcach umownych definicji niezgodnych $\mathrm{z}$ obecnym stanem wiedzy medycznej jest działaniem na niekorzyść ubezpieczonych.

Biorąc pod uwagę przytoczone w tabeli 5 definicje udaru mózgu stosowane przez ubezpieczycieli warto zwrócić uwagę na fakt, iż uzależniają oni uznanie udaru mózgu za wypadek ubezpieczeniowy od potwierdzenia jego wystapienia wynikami badań wykonanych rezonansem magnetycznym lub przy użyciu tomografii komputerowej (TK) : „Rozpoznanie udaru mózgu musi być potwierdzone badaniem tomografii komputerowej lub rezonansu magnetycznego"20. Natomiast rozpoznanie udaru dla lekarza specjalisty nie wymaga potwierdzania go w badaniach neuroobrazowych. Wystarczającym dowodem zatem dla ubezpieczyciela powinna być historia choroby pacjenta, w której znajduje się informacja o postawionej diagnozie i zleconym leczeniu. Co gorsza, można mieć do czynienia z taką sytuacją, że wykonane badania TK głowy do 6-ciu godzin od wystapienia objawów może nie pokazać wyklarowanego ogniska martwicy tkanki nerwowej i wówczas ubezpieczony w swojej dokumentacji medycznej nie będzie miał wymaganych przez ubezpieczyciela dokumentów potwierdzających udar, mimo tego że faktycznie miał on miejsce.

Ponadto zgodnie z definicją WHO udar to ,zespół kliniczny charakteryzujący się nagłym wystapieniem ogniskowego, a niekiedy również uogólnionego zaburzenia czynności mózgu, u którego objawy utrzymują się dłużej niż 24 godziny lub prowadzą wcześniej do śmierci i nie mają przyczyny innej niż naczyniowa".

Analizując definicje stosowane przez ubezpieczycieli wyraźnie widzimy, że mamy do czynienia z zapisami, które mogą wpływać na brak możliwości skorzystania ze świadczeń ubezpieczeniowych, $\mathrm{w}$ tym przypadku podmiotów uposażonych .

Poniżej zestawiono definicje udaru i zawału serca stosowane w ogólnych warunkach ubezpieczeń (OWU) ubezpieczycieli, którzy byli liderami na rynku ubezpieczeń osobowych w 2014 roku. Porównanie ich przedstawiono w tabeli 5.

${ }^{20}$ OWU firmy C. 
Tabela 5. Porównanie definicji wypadków ubezpieczeniowych (zawał serca i udar mózgu) u wybranych ubezpieczycieli

\begin{tabular}{|c|c|}
\hline \multicolumn{2}{|c|}{ Definicja udaru mózgu } \\
\hline $\begin{array}{l}\text { Firma } \\
\text { A }\end{array}$ & $\begin{array}{l}\text { Wystapienie klinicznych objawów nagłego, ogniskowego uszkodzenia mózgu } \\
\text { powstałego w następstwie zaburzeń krążenia mózgowego, powodującego powstanie } \\
\text { trwałych ubytków neurologicznych, potwierdzonych: a) świeżymi zmianami w obrazie } \\
\text { tomografii komputerowej lub rezonansu magnetycznego, b) w wyniku sekcji zwłok, za } \\
\text { wyjątkiem zawału mózgu lub krwawienia śródczaszkowego powodowanego } \\
\text { zewnętrznym urazem, jak również jakichkolwiek epizodów przemijającego } \\
\text { niedokrwienia mózgu (TIA), z tym zastrzeżeniem, iż w rozumieniu niniejszych } \\
\text { warunków ogólnych pojęcie udaru mózgu obejmuje wyłącznie przypadki } \\
\text { sklasyfikowane jako I60, I61, I62 lub I63 według Międzynarodowej Statystycznej } \\
\text { klasyfikacji Chorób i Problemów Zdrowotnych, Rewizja dziesiąta (ICD-10). }\end{array}$ \\
\hline $\begin{array}{l}\text { Firma } \\
\text { B }\end{array}$ & $\begin{array}{l}\text { Epizod krążeniowo-mózgowy wywołujący trwałe } \mathrm{i} \text { nieodwracalne następstwa } \\
\text { neurologiczne (trwające dłużej niż } 24 \text { godziny), któremu towarzyszy trwały } \\
\text { nieodwracalny ubytek neurologiczny, w tym: a) zawał tkanki mózgowej; b) krwotok } \\
\text { wewnatrzczaszkowy lub podpajęczynówkowy; c) zator materiałem pochodzenia poza } \\
\text { czaszkowego. Diagnoza musi być oparta na wszystkich wymienionych poniżej } \\
\text { kryteriach: a) potwierdzone przez lekarza neurologa objawy trwałego uszkodzenia } \\
\text { układu nerwowego, b) zmiany stwierdzone zostały w rezonansie magnetycznym lub } \\
\text { tomografii komputerowej lub innym wiarygodnym badaniem obrazowym } \\
\text { potwierdzającym rozpoznanie świeżo przebytego udaru mózgowego. Nie są objęte } \\
\text { ochroną ubezpieczeniową: a) przemijające niedokrwienie mózgu, b) uszkodzenia mózgu } \\
\text { spowodowane nieszczę́liwym wypadkiem lub urazem. }\end{array}$ \\
\hline $\begin{array}{l}\text { Firma } \\
\text { C }\end{array}$ & $\begin{array}{l}\text { Ostry incydent naczyniowo-mózgowy skutkujący wystapieniem objawów } \\
\text { neurologicznych i obejmujący krwotok wewnątrzczaszkowy lub podpajęczynówkowy, } \\
\text { lub zator materiałem pochodzenia poza czaszkowego, lub zawał tkanki mózgowej. } \\
\text { Rozpoznanie udaru mózgu musi być potwierdzone badaniem tomografii komputerowej } \\
\text { lub rezonansu magnetycznego albo Udar mózgu musi być wskazany jako przyczyna } \\
\text { zgonu w protokole badania sekcyjnego. W rozumieniu OWDU za Udar mózgu nie } \\
\text { uważa się: a) przejściowych ataków niedokrwiennych mózgu (TIA), b) przedłużonych } \\
\text { odwracalnych niedokrwiennych ubytków neurologicznych (PRIND), c) objawów } \\
\text { mózgowych spowodowanych migrena, d) zaburzeń ukrwienia układu przedsionkowego } \\
\text { lub nerwu wzrokowego, e) uszkodzenia mózgu spowodowanego urazem (krwotoki } \\
\text { pourazowe), f) uszkodzenia mózgu w wyniku niedotlenienia (np. w wyniku zatrzymania } \\
\text { krążenia lub oddechu), g) udaru mózgu rozpoznanego jako przebyty w przeszłości, np. } \\
\text { na podstawie tomografii komputerowej lub rezonansu magnetycznego, h) skutków } \\
\text { choroby dekompresyjnej, i) uszkodzenia mózgu spowodowanego przewlekłym } \\
\text { niedokrwieniem. }\end{array}$ \\
\hline \multicolumn{2}{|c|}{ Definicja zawału serca } \\
\hline $\begin{array}{l}\text { Firma } \\
\text { A }\end{array}$ & $\begin{array}{l}\text { Martwica cześsci mięśnia sercowego wywołana nagłym przerwaniem dopływu krwi do } \\
\text { określonego obszaru mięśnia sercowego, której bezpośrednią przyczyną był zawał serca } \\
\text { i do której doszło w okresie } 30 \text { dni od daty rozpoznania zawału serca, potwierdzona: } \\
\text { a) wystąpieniem typowych dla zawału serca objawów klinicznych (typowy ból w klatce } \\
\text { piersiowej, świeżymi zmianami w zapisie EKG potwierdzającymi wystapienie świeżego } \\
\text { zawału serca i znaczącym podwyższeniem stężenia biochemicznych markerów } \\
\text { martwicy mięśnia sercowego we krwi), } \\
\text { b) w wyniku sekcji zwłok, z tym zastrzeżeniem, iż w rozumieniu niniejszych warunków } \\
\text { ogólnych pojęcie zawału serca obejmuje wyłącznie przypadki sklasyfikowane jako I21 } \\
\text { lub I22 według Międzynarodowej Statystycznej Klasyfikacji Chorób i Problemów }\end{array}$ \\
\hline
\end{tabular}




\begin{tabular}{|c|c|}
\hline & \\
\hline & $\begin{array}{l}\text { Martwica części mieśnia sercowego w następstwie niedokrwienia danego obszaru, } \\
\text { której towarzyszy znamienny wzrost wartości biomarkera sercowego roponiny - lub } \\
\text { CK-MB) oraz co najmniej jedno z poniższych: a) stwierdzony w wywiadzie } \\
\text { medycznym typowy ból w klatce piersiowej, b) zmiany w zapisie EKG } \\
\text { charakterystyczne dla niedokrwienia mięśnia sercowego, c) stwierdzenie w badaniu } \\
\text { echokardiograficznym nowych odcinkowych zaburzeń kurczliwości, d) wykrycie } \\
\text { zakrzepu w tętnicy wieńcowej za pomocą angiografii. }\end{array}$ \\
\hline & $\begin{array}{l}\text { Pełnościenna martwica mięśnia sercowego. W rozumieniu OWDU Zawał serca } \\
\text { oznacza: a) wykrycie wzrostu lub spadku stężenia biomarkerow sercowych } \\
\text { (zwłaszcza troponiny), z co najmniej } 1 \text { wartością przekraczającą górną granicę normy } \\
\text { oraz z co najmniej } 1 \mathrm{z} \text { wymienionych niżej dowodów niedokrwienia mięśnia } \\
\text { sercowego: i) objawy kliniczne niedokrwienia mieśnia sercowego (m.in. ból w klatce } \\
\text { piersiowej), ii) zmiany w EKG wskazujące na świeże niedokrwienie - nowe zmiany ST- } \\
\text { T lub nowo powstały blok lewej odnogi pęczka Hisa, iii) powstanie patologicznych } \\
\text { załamków Q w EKG, iv) dowody w badaniach obrazowych ukazujące nowe odcinkowe } \\
\text { zaburzenia kurczliwości miesśnia sercowego, lub b) w przypadku przezskórnych } \\
\text { interwencji wieńcowych (angioplastyka) przy prawidłowych wyjściowych stężeniach } \\
\text { troponin - wzrost stężeń biomarkerow sercowych przekraczający 3-krotnie górną } \\
\text { granice normy, lub c) w przypadku pomostowania tętnic wieńcowych (by-pass) przy } \\
\text { prawidłowych wyjściowych stężeniach troponin - wzrost stężeń biomarkerow } \\
\text { sercowych przekraczający 5-krotnie górną granicę normy, w połączeniu z pojawieniem } \\
\text { się jednego z następujących objawów: i) z nowymi patologicznymi załamkami Q lub } \\
\text { nowo powstałym blokiem lewej odnogi pęczka Hisa, ii) z udokumentowanym } \\
\text { angiograficznie zamknięciem nowego pomostu (by-pass) lub własnej tętnicy } \\
\text { wieńcowej, iii) z dowodami na nową martwicę mięśnia sercowego w badaniu } \\
\text { obrazowym. W rozumieniu OWDU za Zawał serca nie uważa się zawału rozpoznanego } \\
\text { jako przebyty w przeszłości na podstawie obrazu EKG, echokardiografii lub innych } \\
\text { badań diagnostycznych. W rozumieniu OWDU za Zawał serca nie uważa się również } \\
\text { zawału, który nie został stwierdzony w protokole badania sekcyjnego - w przypadku } \\
\text { śmierci przed wykonaniem badania EKG lub badania aktywności enzymów } \\
\text { wskaźnikowych martwicy mięśnia sercowego. }\end{array}$ \\
\hline
\end{tabular}

Źródło: Opracowanie własne na podstawie Ogólnych Warunków Ubezpieczeń :

\section{Wnioski:}

1. W latach 2005-2014 największy udział w sprzedaży ubezpieczeń osobowych (dział I) miały klasyczne ubezpieczenia na życie (grupa 1), w których świadczenie wypłacane jest na wypadek śmierci ubezpieczonego. Ich średni udział w strukturze składki w tym okresie wynosił 51,5\%.

2. W badanych latach obserwowano systematyczny wzrost wartości wypłacanych świadczeń z ubezpieczeń na życie. Ich wartość w 2005 roku wynosiła ok. 4,4 mld zł. a w 2014 było to już ponad 10,5 mld. Należy oczekiwać, że wartość wypłacanych przez ubezpieczycieli świadczeń będzie wzrastała ze względu na wiek klientów posiadających ubezpieczenia na życie.

3. Produkty ubezpieczeniowe są bardzo trudne, jeżeli chodzi o możliwość porównywania ich ze sobą, przez klientów szukających dla siebie optymalnej ochrony. Stosowanie przez ubezpieczycieli w ogólnych warunkach ubezpieczeń (OWU) skomplikowanych definicji zdarzeń, które będą traktowane przez nich 
jako wypadek ubezpieczeniowy, zdecydowanie utrudnia możliwość dokonania racjonalnego wyboru ochrony ubezpieczeniowej

4. Udział liczby osób objętych ubezpieczeniem grupowym na życie w liczbie ogółem ubezpieczonych osób na życie wynosił w 2014 roku ponad $75 \%$, co wskazuje na wciąż większe zainteresowanie Polaków ubezpieczeniami grupowymi niż indywidualnymi.

\section{Literatura}

Członkowska A., Litwin T: Postępowanie diagnostyczne i leczenie w udarze mózgu, http://www.leksykon.com.pl/images/PDF/postepowanie_w_udarze.pdf

Handschke J., Monkiewicz J.,(red.):Ubezpieczenia-podręcznik akademicki, Poltext, 2010

Krajewski M.: Ubezpieczenie na rzecz osoby trzeciej (w:) A. Koch: (red.), Umowa ubezpieczenia Aktualne problemy prawne, Bydgoszcz - Poznań 2005

Leśniak D., Sienicka E., Wojno B.: Zakłady ubezpieczeń i ich usługi, Poradnik KNF. CEDUR. 2014

Luterek A.: Przestępczość ubezpieczeniowa w Polsce. Skala zjawiska (w:) Ubezpieczenia na rzecz gospodarki globalnej sektorów i regionów. I. Jędrzejczyk. (red). Oficyna wydawnicza Edward Mitek, 2015

Maison. D.: Polak w świecie finansów. Wydawnictwo Naukowe PWN, 2013, str139

Nowotarska-Romaniak. B.: Zachowania klientów indywidualnych $\mathrm{w}$ procesie zakupu usługi ubezpieczeniowej, Wolters Kluwer Business, 2013

Ogólne warunki dodatkowego grupowego ubezpieczenia na wypadek śmierci spowodowanej zawałem serca lub krwotokiem śródmózgowym, www.pzu

Ogólne warunki ubezpieczenia indywidualnie kontynuowanego /www.pzu.pl/

PIU (2015) Analiza danych dotyczących przestępstw ujawnionych w 2014 r.

w związku z działalnością zakładów ubezpieczeń- członków Polskiej Izby Ubezpieczeń. https://www.piu.org.pl/

Podstawowe informacje o rozwoju demograficznym Polski do 2014 roku. Notatka informacyjna. GUS. 2015 str.11

GUS (2015). Polski rynek ubezpieczeniowy za lata 2005-2015. Warszawa: GUS.- www.stat.gov.pl Puto M.: Wykluczenie z ubezpieczenia na życie osób dotkniętych określonymi chorobami przewlekłymi, Wiadomości Ubezpieczeniowe 2/2014

Raport roczny KNF 2014 - http://www.knf.gov.pl

Raport Roczny PIU 2015- https://www.piu.org.pl/

Raporty o przestępczości ubezpieczeniowej PIU

Stroiński E. Ubezpieczenia na życie. Teoria i Praktyka. Wydawnictwo Poltext Warszawa 2004

Szczepańska M.: Osoba uprawniona do otrzymania sumy ubezpieczenia w umowie ubezpieczenia na życie (uposażony), Rozprawy Ubezpieczeniowe nr 7(2/2009)

Szczepańska. M.: Ubezpieczenia na życie. Aspekty prawne. Oficyna a Wolters Kluwer business 2008

Śliwiński A.: Ryzyko w ubezpieczeniach na życie taryfy - budowa i optymalizacja, http://www.gu.com.pl/index.php?option=com_content\&view=article\&id=9019\&catid=129:rynekubezpieczeniowy\&Itemid $=151$, data odczytu

Uniwersalna definicja zawału serca. Uzgodnione stanowisko ekspertów European Society of Cardiology, American College of Cardiology, American Heart Association i World Heart Federation (2007). http://www.mp.pl/artykuly/36234

Ustawa z dnia 11 września 2015 r. o działalności ubezpieczeniowej i reasekuracyjnej Dz. U.2015 poz.1844.

Ustawa z dnia 23 kwietnia 1964 r. Kodeks cywilny (Dz. U. z 1964 r. Nr 16, poz. 93, ze zm.) 
Więcko M.: Podstawowe problemy bancassurance w Polsce-raport Rzecznika Ubezpieczonych-co dalej?, Monitor Ubezpieczeniowy nr 37, 2009

\section{Summary}

The aim of the study was to assess the development of life insurance (group 1) in Poland, taking into account factors affecting the number and value of benefits paid and compensation. Analysis covered the period from 2005 to 2014. It was found that life insurance (group1) had the largest share in sales of personal insurance in the analyzed period. The increase in the number of insured persons was accompanied by a 2,5 -fold increase in the value of benefits paid. The study also showed that the share of people insured as a group was much higher than the insured individuals.

Key words: life insurance, group insurance, gross claims paid

Informacja o autorach:

dr inż. Aleksandra Wicka

Katedra Polityki Europejskiej, Finansów Publicznych i Marketingu

Wydział Nauk Ekonomicznych

Szkoła Główna Gospodarstwa Wiejskiego w Warszawie

ul. Nowoursynowska $166 / 6$

02-787 Warszawa

e-mail: aleksandra_wicka@sggw.pl

ppłk Jarosław Świstak

Klinika Neurologiczna

Wojskowy Instytut Medyczny w Warszawie

ul. Szaserów 128

04-141 Warszawa 